\title{
REPRODUCTIVE TRAITS OF THE ESTABLISHED POPULATION OF INVASIVE WESTERN TUBENOSE GOBY, PROTERORHINUS SEMILUNARIS (ACTINOPTERYGII: PERCIFORMES: GOBIIDAE), IN THE VISTULA RIVER, POLAND
}

\author{
Joanna GRABOWSKA*, Dagmara BŁOŃSKA, Lidia MARSZAŁ, and Mirosław PRZYBYLSKI \\ Department of Ecology and Vertebrate Zoology, Faculty of Biology and Environmental Protection, \\ University of Łódź, Poland
}
Grabowska J., Błońska D., Marszał L., Przybylski M. 2019. Reproductive traits of the established population of invasive western tubenose goby, Proterorhinus semilunaris (Actinopterygii: Perciformes: Gobiidae), in the Vistula River, Poland. Acta Ichthyol. Piscat. 49 (4): 355-364.

\begin{abstract}
Background. In Europe, the western tubenose goby, Proterorhinus semilunaris (Heckel, 1837), is the smallest and one of the most expansive species among invasive Ponto-Caspian gobies. The aim of the presently reported study was to investigate reproductive parameters of the tubenose goby population from the Vistula River, as one of the biological traits that might facilitate its successful invasion.

Materials and methods. Fish were sampled monthly from March through October and the following parameters were determined: sex ratio, gonadosomatic index (GSI), fecundity (absolute, relative, batch), oocyte size distribution, and body condition (Fulton's and Clark's indices).

Results. GSI varied considerably between sexes and between individual spring months. The increase of GSI and oocyte diameter distributions indicated that spawning of $P$. semilunaris in the Vistula River lasted from the end of April till July. Multimodal oocytes distribution during reproductive season suggested at least two or three spawning events. The absolute fecundity ranged from 504 to 1250 . The mean batch fecundity ( \pm standard deviation) was $338.35 \pm 89.22$. Both, the absolute and batch fecundity, but not the mean oocyte diameter in the batch, were related to the female standard length. The highest values of Fulton condition index were observed in the reproductive period compared to pre- and post-spawning, while Clark condition index showed a different pattern.
\end{abstract}

Conclusion. The western tubenose goby displays reproductive strategy typical for other fish invaders that successfully naturalized in central Europe.

Keywords: sex ratio, GSI, fecundity, body condition

\section{INTRODUCTION}

The western tubenose goby, Proterorhinus semilunaris (Heckel, 1837) is among the most successful goby species of Ponto-Caspian origin invading inland waters of Europe (Copp et al. 2005). It occurs also in the Laurentian Great Lakes of North America where it was introduced from Europe by ships probably with ballast waters (Kocovsky et al. 2011). Its taxonomic position is problematic. It was recently distinguished as a separate, freshwater species from the genetically divergent, marine Proterorhinus marmoratus (Pallas, 1814) (see Stepien and Tumeo 2006) but later studies (Sorokin et al. 2011) revealed that these two species are in fact euryhaline and distributed in different areas of the Black Sea basin: P. semilunaris in the north-western part of the Black Sea basin (and possibly eastern Aegean basin) and P. marmoratus in the north-eastern part. Thus, as the north-western part of the Black Sea basin is the most probable source of invasive tubenose gobies, dispersing through the Danube and Dnieper river systems to western and central Europe, they are $P$. semilunaris rather than $P$. marmoratus. The western tubenose goby is the smallest species of all the invasive Ponto-Caspian gobies currently that have been currently expanding their range in Europe in this part of Europe. It occupies habitats with available shelters, such as rip-raps but also bottom with rich vegetation and rather slow to moderate water current (Kocovsky et al. 2011, Płąchocki et al.**). It is native to the Black Sea basin and eastern drainage of the Aegean Sea. According to the historical data from the 19th century, the tubenose goby was widely distributed in the Dnieper River (Naseka et al. 2005) and in the Danube up to the Morava River

\footnotetext{
* Correspondence: Dr Joanna Grabowska, Katedra Ekologii i Zoologii Kręgowców, Wydział Biologii i Ochrony Środowiska, Uniwersytet Łódzki, ul. Banacha 12/16, 90-237 Łódź, Poland, phone: (+48) 42 6354433, e-mail: (JG) joanna.grabowska@biol.uni.lodz.pl, (DB) dagmara.blonska@biol.uni.lodz.pl, (LM) lidia.marszal@biol.uni.lodz.pl, (MP)miroslaw.przybylski@biol.uni.lodz.pl.

** Płąchocki D., Kobak J., Poznańska-Kakreko M., Kakareko T. 0000. Environmental factors associated with the occurrence of the Ponto-Caspian gobies in a lowland river belonging to the central European invasion corridor. River Research and Applications. DOI: 10.1002/rra.3543
} 
mouth on the Czech/Slovak border and Vienna in Austria (Ahnelt et al. 1998, Harka and Bíró 2007). Considering the results of Sorokin et al. (2011) it was P. semilunaris rather than $P$. marmoratus. The slow expansion outside its range in the Danube as defined in the 19th century (Harka and Bíró 2007), was observed around 1970 (Ahnelt et al. 1998). Until now, its occurrence was confirmed in several localities in the Danube (Roche et al. 2013), Rhine (Borcherding et al. 2011, Manné et al. 2013), and Meuse (Cammaerts et al. 2012) river systems, however it was less abundant than round goby, Neogobius melanostomus (Pallas, 1814), and bighead goby, Ponticola kessleri (Günther, 1861) (see Borcherding et al. 2011, Manné et al. 2013, Roche et al. 2013). In the Dnieper, that is the first section of the so-called central corridor of invasion for Ponto-Caspian fauna (Bij de Vaate et al. 2002), the invasion of the western tubenose goby was delayed compared to other Ponto-Caspian gobiids (Semenchenko et al. 2011). It appeared in the right tributary of Dnieper, i.e., the Pripyat River (Belarusian part of central corridor) in 2007 (Semenchenko et al. 2011) and soon after in Poland in 2008 (Grabowska et al. 2008), however in the light of recent studies (Sorokin et al. 2011) its taxonomic status needs confirmation by a genetic analysis. It was the first record of the western tubenose goby in the Vistula River system and also in the Baltic Sea basin (Grabowska et al. 2008). It spreads very quickly both the downstream and the upstream of the Vistula River.

Considering the western tubenose goby rapid active dispersal and abundance in the Vistula, we may assume that its reproductive strategy has been very effective and that it has found there suitable abiotic and biotic conditions for the establishment and population increase. The suitability of a particular strategy of an invader may vary depending on the local environmental conditions (Villeneuve et al. 2005, Fox et al. 2007, Britton et al. 2008, Kováč et al. 2009, Záhorská and Kováč 2009). The life-history traits displayed by fish species are a compromise between the genetic heritage of sourcing populations and the constraints posed by the local environment (Reynolds et al. 2005, Blanck et al. 2007). Thus, they can vary considerably in different parts of its range. Moreover, a revision of invasive fish characteristics implied that introduced species are often quite different from natives what can facilitate their establishment and further integration in the new ecosystem (Erös 2005, Vila-Gispert et al. 2005, García-Berthou 2007, Ribeiro et al. 2008, Grabowska and Przybylski 2015). Some of the western tubenose goby populations and their reproductive characteristics have been recently, for the first time, described in its invaded range of distribution (Czech Republic, the Thaya River, known locally as Dyje, Danube basin) (Valová et al. 2015) as well as in lakes of the Marmara Region (north-western Turkey) (Top et al. 2018) that is a part of its native range (Pinchuk et al. 2003, Top et al. 2018). So far they were the only papers undertaking these aspects of its biology. Although some fragmentary data of the species lifehistory traits were provided in several earlier papers, they must be taken with caution as they all concerned
Proterorhinus marmoratus in its native range before the taxonomic revision (Stepien and Tumeo 2006, Sorokin et al. 2011) of the species and included both marine/estuarine and freshwater populations that later were identified as separate taxa.

In the presently reported study, we aimed at evaluating the western tubenose goby reproductive characteristics from the Vistula River (invaded range, central invasion corridor) to contribute to very limited knowledge of the biology of this invasive species rapidly expanding its range in Europe.

\section{MATERIALS AND METHODS}

The presently reported study was carried out in 2014 in the tailwater of the Włocławek Reservoir located in the lower section of the Vistula River near the town of Płock, Poland $\left(52^{\circ} 32^{\prime} 05^{\prime \prime} \mathrm{N}, 019^{\circ} 41^{\prime} 12^{\prime \prime} \mathrm{E}\right)$. Tubenose gobies were sampled monthly from March to August and in October by electrofishing gear (type EFGI 650, BSE Bretschneider Spezialelektronik, Germany) wading along the rip-rap shoreline at the depth of $0.2-0.7 \mathrm{~m}$ on the sandy-stony bottom with scattered single patches of the submerged plants. Fish were euthanized with an overdose of clove oil and preserved in $4 \%$ formaldehyde.

At the laboratory, fish were measured for total (TL) and standard (SL) length to the nearest $1 \mathrm{~mm}$ and weighed ( $W_{\mathrm{T}}=$ total body weight) to the nearest $0.01 \mathrm{~g}$. Then, all individuals were dissected and sex was determined by the gonad examination. Gonads of females and males were removed and weighed ( $W_{\mathrm{g}}=$ gonad weight) to the nearest $0.001 \mathrm{~g}$ (wet weight). The gonadosomatic index (GSI) was calculated as:

$$
\mathrm{GSI}=100 W_{\mathrm{g}} \cdot W_{\mathrm{T}}^{-1}
$$

Each eviscerated fish was weighed $\left(W_{\text {evc }}=\right.$ eviscerated body weight). Two tissue sub-samples from the middle part of the ovary, covering the whole cross-section, were extracted and weighed to the nearest $0.001 \mathrm{~g}$. The subsamples were placed in one layer on microscopic slides immersed in glycerine solution and photographed using a digital camera (Olympus DP 70) mounted on a binocularmicroscope $(20 \times, 25 \times$, and $32 \times$ zoom; Olympus SZX7). The diameters of 30-40 randomly sampled oocytes from each female were measured using LUCIA 5 image analysis software and pooled in the following sampling dates to plot the length-frequency diagrams.

Based on the rapid increase of GSI values and the development of oocytes in gonads (emergence of large, yolked oocyte $>1 \mathrm{~mm}$ fraction in length-frequency diagrams) in the consecutive sampling dates, the sample collected on 29 April, was selected for further analysis of fecundity as representative for the beginning of the spawning period. For each of the 62 females collected at that date (Table 1), all oocytes in the two sub-samples of ovary tissue, i.e., from 175 to 200 oocytes, were counted and their diameters were measured using LUCIA 5 image analysis software to plot length-frequency diagram. Only females with ovaries containing ripe, yolked oocytes were considered in the fecundity analysis. The total number 
of vitellogenic oocytes was counted by the gravimetric method (Murua et al. 2003) to determine the absolute fecundity $\left(F_{\mathrm{a}}\right)$ and the relative fecundity $\left(F_{\mathrm{r}}\right)$, i.e., the number of oocytes per $1 \mathrm{~g}$ of body weight. The batch fecundity $\left(F_{\mathrm{b}}\right)$ defined as the number of eggs spawned per batch, was estimated by the oocytes size-frequency method (Hunter et al. 1985). To estimate the batch fecundity $\left(F_{\mathrm{b}}\right)$ the most advanced modal group of oocyte size classes was determined from the diagrams. The mode composed of the largest oocytes, i.e., $>1 \mathrm{~mm}$ of diameter. Their proportion in sub-sample was used to estimate the number of largest oocytes in the ovary.

Additionally, on 10 May 10 individuals (5 females with swollen bellies indicating ripe gonads and 5 males with black spawning colouration) were collected for aquarium observation and after 3 days they laid eggs. The sample of 71 eggs was photographed under a binocular microscope and their two diameters, as they were elliptical, were measured using LUCIA 5 image analysis software.

The body condition was expressed using Fulton's and Clark's condition indices. The former (Le Cren 1951) was determined using the following formula

$$
K_{\mathrm{F}}=\frac{100000 \cdot W_{\mathrm{T}}}{\mathrm{TL}^{3}}
$$

where $W_{\mathrm{T}}$ was the total body weight [g], TL was the total length [mm].

The Clark's condition index was calculated based on the following formula

$$
K_{C}=\frac{100000 \cdot W_{\mathrm{evc}}}{\mathrm{TL}^{3}}
$$

where $W_{\text {evc }}$ was the eviscerated fish body weight [g], TL was the fish total length [mm] (Bagenal and Tesch 1978).
Statistical analyses. Sex ratio was calculated as the number of males divided by the total number of individuals (males plus females) in the sample. On each monthly sample, the chi-squared analysis $\left(\chi^{2}\right)$ was used to test whether the sex ratio deviated from $1 \div 1$ parity (Zar 2010). To compare mean values of standard length between sexes, the $t$-test was used. The relations between eviscerated body weight $\left(W_{\text {evc }}\right)$, gonad weight $\left(W_{\mathrm{g}}\right)$, and standard length (SL) were determined by linear regression (log-transformed data). The differences of regression coefficients of relation $W_{\text {evc }}$ and SL between sexes were tested using $t$-test (Zar 2010), while the analysis of covariance (ANCOVA) was applied to test differences among seasons (sample date) (Zar 2010). The effect of the season (sample date) and sex on GSI, $K_{\mathrm{F}}$ and $K_{\mathrm{C}}$ variation were tested using two-way analysis of variance (ANOVA II). Prior, the assumption of analysis, i.e., the normal distribution of variables was checked using the Shapiro-Wilk test and the homoscedasticity of variance was tested using the Levene test. If the analysis of variance showed a significant effect of any of the factors, a multiple-comparison, i.e., the Fisher Least Significant Difference (LSD) test (post-hoc test) was used. All analysis were made using STATISTICA 10 software.

\section{RESULTS}

The standard length (SL) of 233 females collected from March through August and in October 2014 ranged from 31 to $66 \mathrm{~mm}$. The 136 examined males represented a wider range length, i.e., from 33 to $72 \mathrm{~mm}$ (Table 1). The relation between SL and TL was described by the equations, i.e., males: $\mathrm{SL}=0.85 \times \mathrm{TL}-3.24, r^{2}=0.99$, $P>0.001$, females: $\mathrm{SL}=0.84 \times \mathrm{TL}-2.48, r^{2}=0.97, P>$ 0.001 . In general, females were significantly smaller than males $\left(\mathrm{SL}_{\mathrm{F}}=42.4 \pm 4.6, \mathrm{SL}_{\mathrm{M}}=51.9 \pm 9.0, t=13.31\right.$, df $=366, P<0.001)$. The weight of males ranged from 0.71

Table 1

\begin{tabular}{|c|c|c|c|c|c|c|c|c|c|}
\hline \multirow{2}{*}{ Sampling date } & \multirow{2}{*}{ S } & \multirow{2}{*}{$N$} & \multicolumn{2}{|c|}{ Total length } & \multicolumn{2}{|c|}{ Standard length } & \multicolumn{3}{|c|}{ Sex ratio } \\
\hline & & & Mean \pm SD & Min-max & Mean \pm SD & Min-max & $M \div F$ & $\chi^{2}$ & $P$ \\
\hline \multirow{2}{*}{25 March } & $\mathrm{F}$ & 40 & $54.00 \pm 6.23$ & $41-77$ & $42.00 \pm 5.50$ & $31-62$ & \multirow{2}{*}{$1 \div 1.1$} & \multirow{2}{*}{0.05} & \multirow[b]{2}{*}{ n.s } \\
\hline & $\mathrm{M}$ & 38 & $58.00 \pm 10.78$ & $42-78$ & $46.00 \pm 9.07$ & $33-61$ & & & \\
\hline \multirow{2}{*}{8 April } & $\mathrm{F}$ & 10 & $52.00 \pm 3.35$ & $45-58$ & $41.00 \pm 3.57$ & $35-41$ & \multirow{2}{*}{$1 \div 0.7$} & \multirow{2}{*}{1.00} & \multirow{2}{*}{ n.s. } \\
\hline & M & 15 & $71.00 \pm 7.03$ & $55-82$ & $57.00 \pm 6.07$ & $43-67$ & & & \\
\hline \multirow{2}{*}{29 April } & $\mathrm{F}$ & 62 & $53.00 \pm 4.41$ & $44-67$ & $42.00 \pm 3.94$ & $35-53$ & \multirow{2}{*}{$1 \div 3.4$} & \multirow{2}{*}{24.20} & \multirow{2}{*}{$<0.001$} \\
\hline & $\mathrm{M}$ & 18 & $70.00 \pm 8.51$ & $48-84$ & $56.00 \pm 7.45$ & $39-70$ & & & \\
\hline \multirow{2}{*}{19 May } & $\mathrm{F}$ & 54 & $55.00 \pm 4.79$ & $48-74$ & $44.00 \pm 4.08$ & $38-60$ & \multirow{2}{*}{$1 \div 2.7$} & \multirow{2}{*}{15.62} & \multirow{2}{*}{$<0.001$} \\
\hline & $\mathrm{M}$ & 20 & $71.00 \pm 7.71$ & $52-80$ & $57.00 \pm 6.57$ & $42-65$ & & & \\
\hline \multirow{2}{*}{12 June } & $\mathrm{F}$ & 25 & $53.00 \pm 4.59$ & $46-62$ & $43.00 \pm 3.99$ & $43-50$ & \multirow{2}{*}{$1 \div 2.8$} & \multirow{2}{*}{7.53} & \multirow{2}{*}{$<0.01$} \\
\hline & $\mathrm{M}$ & 9 & $68.00 \pm 9.94$ & $47-77$ & $54.00 \pm 8.14$ & $37-62$ & & & \\
\hline 17 July & $\mathrm{J}$ & 38 & $37.00 \pm 3.83$ & $30-46$ & $30.00 \pm 3.09$ & $24-37$ & - & & \\
\hline \multirow{2}{*}{12 August } & $\mathrm{J}$ & 9 & $42.00 \pm 3.09$ & $37-47$ & $35.00 \pm 2.57$ & $31-39$ & \multirow{2}{*}{ - } & & \\
\hline & M & 1 & 58.00 & & 47.00 & & & & \\
\hline \multirow{2}{*}{23 October } & $\mathrm{F}$ & 42 & $51.00 \pm 6.43$ & $40-69$ & $42.00 \pm 5.47$ & $32-58$ & \multirow{2}{*}{$1 \div 1.2$} & \multirow{2}{*}{0.64} & \multirow{2}{*}{ n.s. } \\
\hline & M & 35 & $61.00 \pm 8.42$ & $42-85$ & $50.00 \pm 7.49$ & $34-72$ & & & \\
\hline
\end{tabular}

Characteristics of western tubenose goby, Proterorhinus semilunaris, from the Vistula River in 2014

$\mathrm{S}=\operatorname{sex}, N=$ number of individuals, $\mathrm{SD}=$ standard deviation, $\mathrm{M}=$ male, $\mathrm{F}=$ female, $\mathrm{J}=$ juvenile; deviations from $1 \div 1$ sex ratio were tested with binominal test $(P<0.05)$, n.s. $=$ non-significant difference. 
to $8.60 \mathrm{~g}$ and females from 1.15 to $3.94 \mathrm{~g}$. Eviscerated weight was significantly related to standard length (Table 2 ). The comparisons of $b$ coefficients revealed that males were heavier than females of the analogous standard length (SL). Only in April samples, such differences were not significant (Table 2).

Sex ratio. The sex ratio in samples differed significantly from $1 \div 1$ since the end of April to June when females constituted $73 \%-75 \%$ of sampled adults. In the prespawning period, i.e., in March, beginning of April, and in post-reproduction season, i.e., in October, the abundance of both sexes was balanced (Table 1).

Gonadosomatic index. All females sampled between March and June were sexually mature. Gonad weight was positively correlated with body length (SL) in both sexes from March to June, except for females in June (Table 3). Gonadosomatic index (GSI) varied considerably between sexes $\left(F_{1,281}=110.99, P<0.0001\right)$ and across spring months $\left(F_{4,281}=19.78, P<0.0001\right)$ with significant sex $\times$ month interaction $\left(F_{4,281}=13.42, P<0.0001\right)$ (Fig. 1). The GSI for males did not change significantly across the examined period, while the GSI for females increased four times from March to end of April. Then, in the subsequent spawning months, the GSI values for females did not differ significantly. Except for March and early April, the GSI values were considerably higher for females than for males (Fig. 1). The GSI values did not correlate with female and male standard length (SL) except for one sampling date (8 April) when such relation was confirmed by linear regression (females: $a=-5.29 \pm 1.75, b=3.70 \pm$ $1.09, r^{2}=0.59, P>0.01$ and males: $a=-2.96 \pm 0.58, b=$ $\left.1.86 \pm 0.33, r^{2}=0.71, P>0.001\right)$.

Eggs. Oocyte diameter distributions in the consecutive dates during spawning season indicated that spawning in the studied section of the Vistula River in 2014 began at the end of April and lasted, at least, to July (Fig. 2). The

Table 2

Standard length-eviscerated body weight relations (log-transformed data) for the western tubenose goby, Proterorhinus semilunaris, in the Vistula River in 2014

\begin{tabular}{|c|c|c|c|c|c|c|c|c|c|c|}
\hline \multirow{2}{*}{ Sampling date } & \multirow{2}{*}{ Sex } & \multirow{2}{*}{$a$} & \multirow{2}{*}{$\mathrm{SE} a$} & \multirow{2}{*}{$b$} & \multirow{2}{*}{$\mathrm{SE} b$} & \multirow{2}{*}{$N$} & \multicolumn{2}{|c|}{$r^{2}$} & \multicolumn{2}{|c|}{$t$-test } \\
\hline & & & & & & & Value & $P$ & Value & $P$ \\
\hline \multirow{2}{*}{25 March } & $\mathrm{F}$ & -4.203 & 0.417 & 2.693 & 0.258 & 40 & 0.741 & 0.001 & \multirow{2}{*}{2.371} & \multirow{6}{*}{$<0.05$} \\
\hline & M & -5.156 & 0.131 & 3.266 & 0.079 & 38 & 0.979 & 0.001 & & \\
\hline \multirow{2}{*}{8 April } & $\mathrm{F}$ & -5.675 & 0.482 & 3.608 & 0.300 & 10 & 0.948 & 0.001 & \multirow{2}{*}{0.485} & \\
\hline & M & -5.385 & 0.336 & 3.435 & 0.191 & 15 & 0.961 & 0.001 & & \\
\hline \multirow{2}{*}{29 April } & $\mathrm{F}$ & -4.723 & 0.175 & 2.992 & 0.108 & 62 & 0.928 & 0.001 & \multirow{2}{*}{1.722} & \\
\hline & M & -5.142 & 0.250 & 3.291 & 0.143 & 18 & 0.971 & 0.001 & & \\
\hline \multirow{2}{*}{19 May } & $\mathrm{F}$ & -4.561 & 0.191 & 2.885 & 0.117 & 54 & 0.922 & 0.001 & \multirow{2}{*}{3.343} & \multirow{2}{*}{$<0.01$} \\
\hline & $\mathrm{M}$ & -5.518 & 0.264 & 3.506 & 0.150 & 20 & 0.968 & 0.001 & & \\
\hline \multirow{2}{*}{12 June } & $\mathrm{F}$ & -3.925 & 0.216 & 2.467 & 0.133 & 25 & 0.938 & 0.001 & \multirow{2}{*}{3.562} & \multirow{2}{*}{$<0.001$} \\
\hline & M & -5.133 & 0.378 & 3.257 & 0.219 & 9 & 0.969 & 0.001 & & \\
\hline \multirow{2}{*}{23 October } & $\mathrm{F}$ & -5.086 & 0.127 & 3.187 & 0.079 & 42 & 0.976 & 0.001 & \multirow{2}{*}{5.786} & \multirow{2}{*}{$<0.001$} \\
\hline & M & -4.731 & 0.127 & 2.986 & 0.075 & 35 & 0.980 & 0.001 & & \\
\hline
\end{tabular}

$N=$ number of fish studied, $r^{2}=$ coefficient of determination; $\mathrm{M}=$ male, $\mathrm{F}=$ female; $a=$ intercept, $b=$ slope, $\mathrm{SE}=$ standard error, Sexspecific differences in slopes for each sample occasion were tested with $t$-test.

Table 3

Regression of gonad weight on standard length (log-transformed data) for western tubenose goby, Proterorhinus semilunaris, in the Vistula River in 2014

\begin{tabular}{lcccccccc}
\hline \multicolumn{1}{c}{ Sampling date } & Sex & $a$ & SE $a$ & $b$ & SE $b$ & $N$ & $r^{2}$ & $P$ \\
\hline \multirow{2}{*}{25 March } & $\mathrm{F}$ & -6.658 & 0.772 & 3.310 & 0.477 & 40 & 0.56 & $<0.001$ \\
& $\mathrm{M}$ & -4.430 & 0.772 & 1.764 & 0.467 & 38 & 0.28 & $<0.001$ \\
\hline \multirow{2}{*}{ A April } & $\mathrm{F}$ & -13.074 & 2.152 & 7.432 & 1.339 & 10 & 0.79 & $<0.001$ \\
& $\mathrm{M}$ & -10.123 & 0.588 & 5.198 & 0.335 & 15 & 0.95 & $<0.001$ \\
\multirow{2}{*}{ 29 April } & $\mathrm{F}$ & -5.400 & 1.268 & 2.885 & 0.779 & 62 & 0.19 & $<0.001$ \\
& $\mathrm{M}$ & -8.966 & 1.567 & 4.548 & 0.897 & 18 & 0.62 & $<0.001$ \\
\hline \multirow{2}{*}{ 19 May } & $\mathrm{F}$ & -5.587 & 1.325 & 3.009 & 0.808 & 54 & 0.21 & $<0.001$ \\
& $\mathrm{M}$ & -4.494 & 1.675 & 2.051 & 0.954 & 20 & 0.20 & $<0.05$ \\
\hline \multirow{2}{*}{ 12 June } & $\mathrm{F}$ & -4.512 & 3.090 & 2.188 & 1.897 & 25 & 0.05 & $>0.05$ n.s. \\
& $\mathrm{M}$ & -6.267 & 1.752 & 2.965 & 1.012 & 9 & 0.55 & $<0.05$ \\
\hline
\end{tabular}

$N=$ number of fish studied, $r^{2}=$ coefficient of determination; $\mathrm{M}=$ male, $\mathrm{F}=$ female; $a=$ intercept, $b=$ slope, $\mathrm{SE}=$ standard error. 


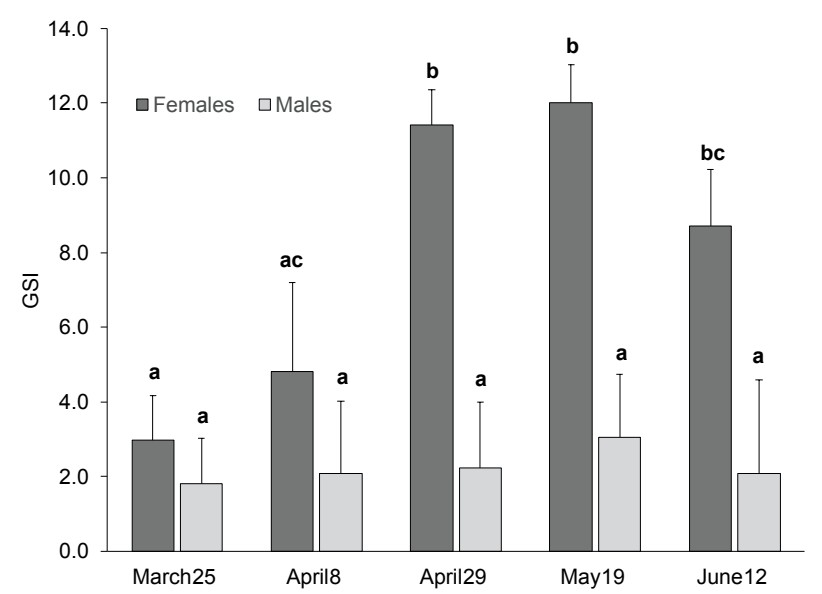

Fig. 1. Gonadosomatic index (GSI) (mean $\pm 95 \% \mathrm{CL}$ ) of western tubenose goby, Proterorhinus semilunaris, in the Vistula River, from March to June 2014; the same letters denote groups that did not statistically differ (the LSD Fisher post-hoc test)

multimodal character distribution revealed the presence of oocytes at different stages of development in population during the studied period March-June, ranging in total from 0.15 to $1.92 \mathrm{~mm}$. Diagrams plotted for pooled data for 52 females sampled on 29 April allowed to distinguish three oocyte size groups: small 0.15 to $<0.5 \mathrm{~mm}$, medium 0.5 to $<1 \mathrm{~mm}$, and large from 1 to $1.92 \mathrm{~mm}$. However, the oocytes size distribution of individual female was always bimodal with one fraction of large and one of the small oocytes (Fig. 3 ). The fraction of the largest oocytes $>1 \mathrm{~mm}$ was present in ovaries of about $75 \%$ of females at the end of April and it was clearly separated by a gap, i.e., lack of intermediate sizes oocytes, from the fraction of small eggs, i.e., 0.15 to $0.7 \mathrm{~mm}$. In ovaries of females in which no fraction of the largest eggs was observed, two peaks in the diagrams were also distinguished, i.e., 0.15 to $0.55 \mathrm{~mm}$ and 0.60 to $95 \mathrm{~mm}$, but with no gap in-between. The presence of the largest oocyte fraction in ovaries did not correspond with female size as it was present both in small and large females ovaries at the same time of the spawning period.

The longer diameter of the already deposited elliptic eggs was $2.966 \pm 0.226 \mathrm{~mm}$ (mean \pm standard deviation, $\mathrm{SD})$ and the shorter one was $1.428 \pm 0.125 \mathrm{~mm}$.

Fecundity. The absolute fecundity $\left(F_{\mathrm{a}}\right)$ ranged from 504 to $1250(809.7 \pm 211.5)$ oocytes for females of length (SL) ranging from $38-50 \mathrm{~mm} . F_{\mathrm{a}}$ increased with female length following linear regression formula: $F_{\mathrm{a}}=41.91 \times \mathrm{SL}-$ $987.99\left(n=43, r^{2}=0.57, P>0.001\right)$. Mean relative fecundity was $407.2 \pm 93.0$ and ranged from 208 to 758 . The mean batch fecundity $\left(F_{\mathrm{b}}\right)$ was $\left.338.35 \pm 89.22\right)$ and ranged from 212 to 525 . It was related to female standard length following linear regression formula: $F_{\mathrm{b}}=12.33 \times \mathrm{SL}-176.85(n=$ $\left.43, r^{2}=0.28, P>0.001\right)$. The mean oocytes diameter in the batch, i.e., the largest eggs fraction, was not correlated with female standard length $\left(r^{2}=0.265, P=0.088\right)$.

Condition. The Fulton's condition index $\left(K_{\mathrm{F}}\right)$ varied significantly across months $\left(F_{5,356}=77.12, P<0.0001\right)$ as well as between sexes $\left(F_{1,356}=65.85, P<0.0001\right)$
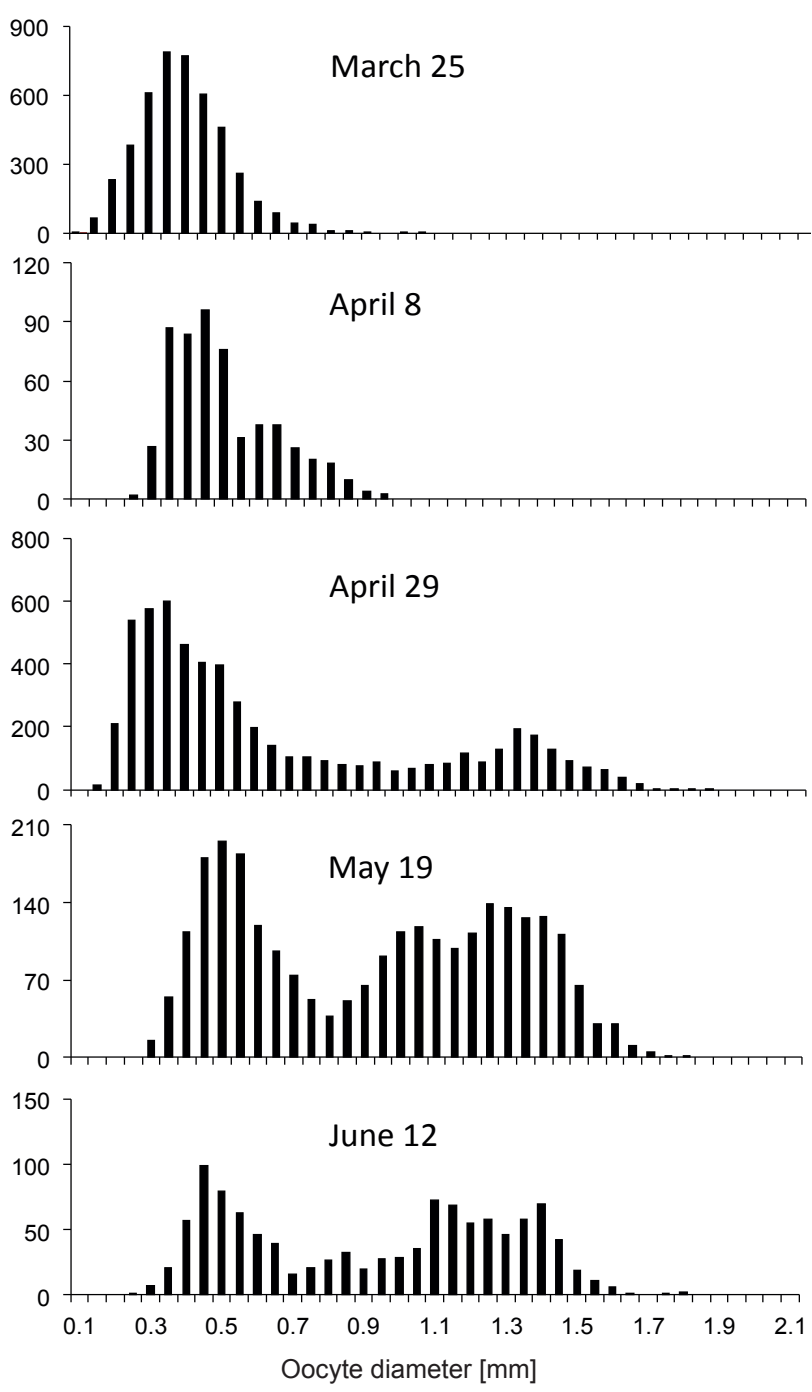

Fig. 2. Size-frequency distribution of oocytes from the ovaries of individuals of western tubenose goby, Proterorhinus semilunaris, in the Vistula River during the reproductive period in 2014

(Fig. 4) with significant interaction between months and sex $\left(F_{5,356}=5.81, P<0.0001\right)$. Males and females showed a similar pattern of $K_{\mathrm{F}}$ variation when the highest values of the index were observed since early April to June and the lowest in March and in October. Moreover, at this period, the $K_{\mathrm{F}}$ values for males were higher than that for females except for March, when there was no such difference (Fig. 4). Higher differences in condition between males and females were revealed in a variation of Clark's index $\left(K_{\mathrm{C}}\right)$ (Fig. 5). This index also varied between sexes $\left(F_{1,355}=272.86, P<0.0001\right)$ and months $\left(F_{5,355}=31.53, P<0.0001\right)$ with significant interaction of that two variables $\left(F_{5,355}=22.78, P<0.0001\right)$. Apart from March $K_{\mathrm{C}}$ values for males were higher than for females. Across the examined season, Clark's index values for females showed no differences apart of June when the lowest value of $K_{\mathrm{C}}$ was noted, meanwhile, for males, this index varied between months as from early April to May its values were aligned and significantly higher than in March, June, and October (Fig. 5). 


\section{DISCUSSION}

The western tubenose goby displays reproductive strategy that is typical for all gobiids, including nest spawning and brood guarding by a male (Miller 1984). It involves the larger body size of male compared to females (Miller 1984, Wootton 1998). Indeed, western tubenose goby males in our study had their standard length approximately by 30 percentage points bigger and their eviscerated body was heavier than the body of females of the same length. Similar sex-dependent size difference during the reproductive period was observed in western tubenose goby in the Thaya (Dyje) River (a tributary of lower Morava River, Danube basin) by Prášek (unpublished*) and Valová et al. (2015).

Sex ratio. The sex ratio of tubenose goby in our samplings was female biased during months of the most intensive spawning, i.e., at the end of April, in May, and in June but was balanced in the pre-spawning (March) and postreproductive (October) period. It can be explained by gobies spawning behaviour, i.e., males stay in the nests under stones and in other crevices while females swim nearby (Meunier et al. 2009) and thus, a sampling of hidden males is much less efficient than in case of females (Brandner et al. 2013). As the water temperature increases in the early spring, western tubenose gobies migrate to shore from the deeper parts of the water body where they spend the winter (Valová et al. 2015), and is considered that males arrive slightly earlier than females to find and take the most suitable shelter for the nest (Kovtun 1979, Moskal'kova 1996). Thus the sex ratio in the pre-spawning period depends on the moment of sampling and can be balanced like in our study and like recorded by Prášek (unpublished*) or female dominated (Valová et al. 2015). The sex ratio $1 \div 1$ in post-reproductive months, similar like in our study, was reported by Prášek (unpublished*) and Valová et al. (2015).

Spawning. According to literature, tubenose gobies mature in their second year of life (Pinchuk et al. 2003). Valová et al. (2015) suggested that in the Thaya (Dyje) River all hatched individuals that survived the winter were ready to spawn in the next spawning season, i.e., at the age $1+$. It would explain why, in our studies, all females sampled between March and June were mature. Thus, the approximate age at first maturity ranged between the end of $0+$ and $1+$, depending on the exact month of hatching. The smallest females with ripe oocytes, i.e., larger than $1 \mathrm{~mm}$ in diameter in gonads had a total length of 46-47 $\mathrm{mm}$. In our samples, mature individuals smaller than 41
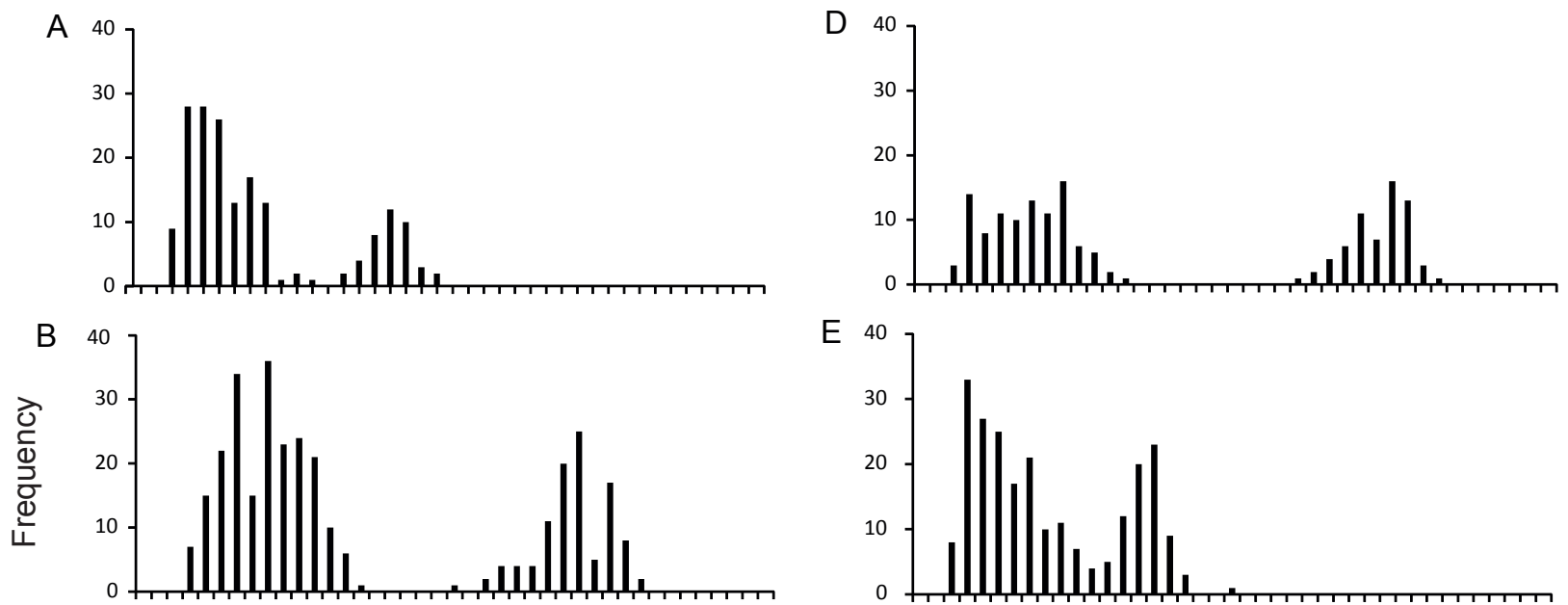

E 40


Oocyte diameter [mm]

Fig. 3. Size-frequency distribution of oocytes from the ovaries of western tubenose goby, Proterorhinus semilunaris, females sampled on 29 April in the Vistula River; (A) female with standard length of $37 \mathrm{~mm}$, (B) $38 \mathrm{~mm},(\mathbf{C}) 43 \mathrm{~mm}$, (D) $44 \mathrm{~mm}$, (E) $51 \mathrm{~mm},(\mathbf{F}) 50 \mathrm{~mm}$

\footnotetext{
" Prášek V. 2006. Biologie hlavačky mramorované (Proterorhinus marmoratus), nového druhu ichthyofauny České republiky. [Biology of the tubenose goby (Proterorhinus marmoratus), a new species of the ichthyofauna of the Czech Republic.] Doctoral thesis, Masarykova univerzita, Prrírodovědecká fakulta [Masaryk University, Faculty of Science] Brno, Czech Republic.
} 


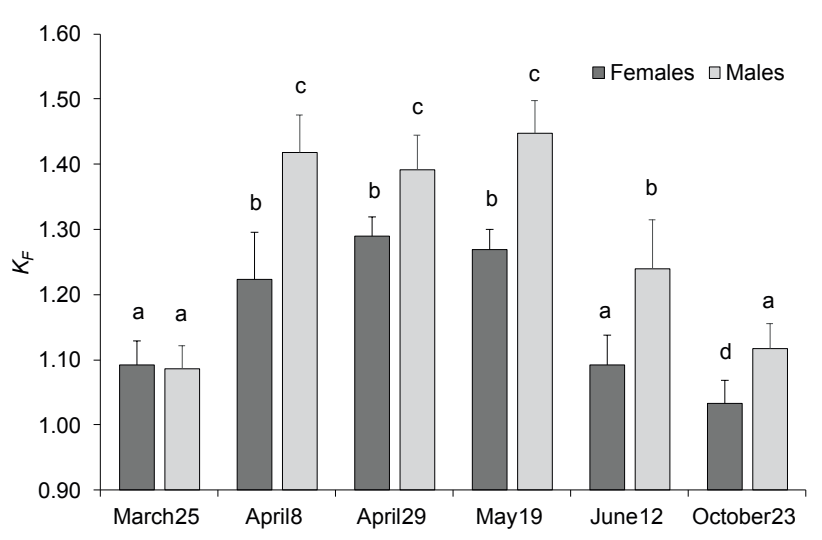

Fig. 4. Fulton's condition index $\left(K_{\mathrm{F}}\right)$ (mean $\pm 95 \% \mathrm{CL}$ ) of western tubenose goby, Proterorhinus semilunaris, in the Vistula River, from March to June 2014; the same letters denote groups that did not statistically differ (the LSD Fisher post-hoc test)

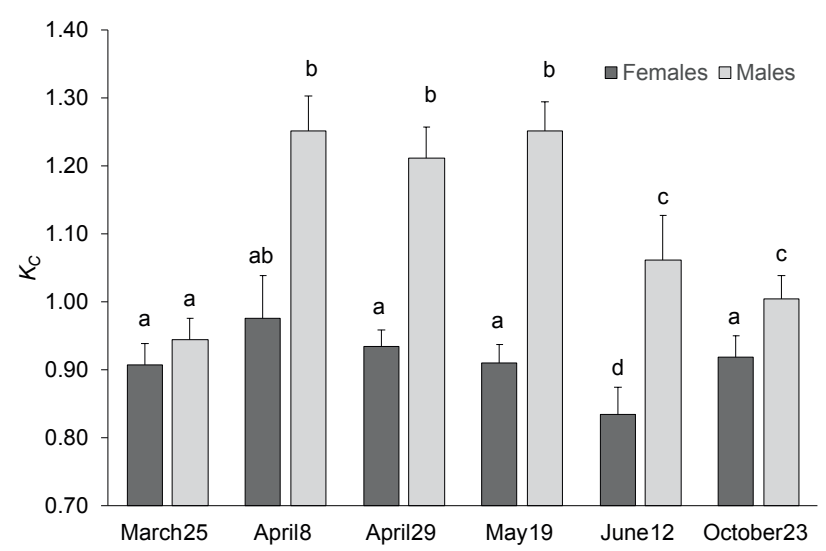

Fig. 5. Clark's condition index $\left(K_{\mathrm{C}}\right)$ (mean $\left.\pm 95 \% \mathrm{CL}\right)$ of western tubenose goby, Proterorhinus semilunaris, in the Vistula River, from March to June 2014; the same letters denote groups that did not statistically differ (the LSD Fisher post-hoc test)

$\mathrm{mm}$ (female) and $42 \mathrm{~mm}$ (male) were not observed, while the total length of maturity in the Marmara region, northwestern Turkey (part of the native range), was estimated at 38-42 $\mathrm{mm}$ for female and 33-37 $\mathrm{mm}$ for male (Top et al. 2018). In the Thaya (Dyje) River (the Czech Republic; invasive range in the Danube River system) female of similar length had ripe gonads (Valová et al. 2015). It indicates that western tubenose goby mature early and at very small body length.

The rapid increase of GSI between the beginning and the end of April implies that spawning in the Vistula River in the studied year started at the end of April when the water temperature at the shore was $16.5^{\circ} \mathrm{C}$ and lasted at least till July. However, we collected almost no adults in July and August as fishing was almost impossible due to the low water level in the Vistula that dropped down so extremely in the sampling site that entirely exposed a wide area of bottom including the rip-rap habitats usually occupied by adults of the western tubenose goby. The same duration of the reproductive season was observed in the Thaya (Dyje) River (Czech Republic) or was even prolonged to August in more southern regions of the species distribution range, i.e., in Hungary (Harka and Farkas 2006) and Bulgaria (Georgiev 1966). According to Valová et al. (2015), the gonad development of western tubenose goby started in October, with the most intensive growth in March and April, what we observed also in our studies. Readiness to spawning was indicated also by the appearance of the largest oocytes, i.e., of the diameter $>$ $1 \mathrm{~mm}$, in ovaries that constituted pronounced separated fraction. The fraction of such oocytes was not present in ovaries of any female on 8 April and after the next three weeks, three-quarters of females had it in ovaries. There was no relation between the presence of large oocytes fraction in ovaries and the size of females, contrary to the suggestion that larger females begun spawning earlier than smaller (Miranda and Muncy 1987). The first juveniles in our studies were observed in July, probably recruited from the first spawning event at the end of April. Considering the range of their standard length, i.e., from 28 to $40 \mathrm{~mm}$ $(30.2 \pm 3.8 \mathrm{~mm})$ they hatched at least a month earlier but were not found any juveniles in June's sample. Valová et al. (2015) noted first YOY of mean standard length $14.8 \pm$ $0.4 \mathrm{~mm}$ in June and these increased in number and size in subsequent dates.

Eggs. The multimodal character of oocyte distribution diagrams in subsequent months indicated at least two or three spawning events in the studied population of the western tubenose goby during the reproductive season, but the diagrams plotted separately for each female suggest that an individual female spawned twice per season. It is consistent with the previous studies (Valová et al. 2015), where female gonads prior to the spawning season contained two or three clearly distinguished groups of oocytes. The gap between a batch of largest oocytes, i.e., ready to spawn, and the remained smaller oocytes in ovaries suggest the presence of a lag phase in the development of the oocytes between consecutive spawning events. The high variation of GSI for both sexes observed in all samples taken during reproductive season indicates an asynchronous spawning. Such a conclusion is also supported by the multimodal character of oocyte distribution in ovaries of individual females sampled on the same date.

Fecundity. The absolute fecundity of western tubenose goby in the Vistula River was of similar range and with same mean values like in the Thaya (Dyje) River (Valová et al. 2015), while the mean relative fecundity was higher. However, we realize that this parameter is regulated by many factors, e.g., by nutritional status and environmental condition as well as by the female size. The absolute fecundity and gonad weight of western tubenose goby was correlated with the female standard length, like in the Thaya (Dyje) River (Valová et al. 2015). The absolute fecundity is difficult to estimate in species that are multiple spawners, like gobies, as it depends on the number of batches released and a number of oocytes in each batch (Hunter and Goldberg 1980). The number of eggs, as well 
as their size, might be different in the following spawning events. We found that larger females had more oocytes in the batch, but the size of oocytes ready to lay, i.e., the mean diameter of oocytes in the batch of the largest ones, was not correlated with the female size. Similarly, the relation between batch fecundity and the female length was found in round goby but only in the case of the first batch in the season while it was not present in the second one (Tomczak and Sapota 2006).

Condition. According to our observations, there was no significant difference in the condition between females and males, prior to the spawning season, at the beginning of March. Later, such differences appeared due to different investment in the reproduction of both sexes, i.e., females invest more resources in gonad development than males. In the consecutive months of the spawning activity, Fulton's index for both sexes remained higher than in March but it resulted from the contribution of ripe (full-grown) gonads to the fish body weight. Meanwhile, if the condition is expressed with Clark's index, where eviscerated body weight, i.e., without gonads, is used for its estimation, there was no difference in the condition of females across the studied period, except for June, when its value decreased considerably. A similar abrupt decrease in the condition in June was observed for males. It is a cost of reproduction that involves translocation of energy from somatic growth to gonad building and energy-demanding nest guarding of males. The better body condition of males indicates their higher competitive abilities and influences the superior position in comparison with other males in population (Grabowska et al. 2019). Thus, the higher values of Clark's coefficient observed for males in April and May, compared with other non-reproductive seasons, might be associated with competition for the best nesting sites and, as a consequence, it influences the reproductive success. However, the costs of intraspecific competition, nest defence, and prolonged food deficiency as a side effect of nest occupation, increase in the consecutive months. Thus, it inevitably leads to a drop in males' condition. In October, when females and males were two-three months after spawning and had time to rebuild their body condition, the difference in the condition was insignificant.

Conclusion. The population of western tubenose goby in the Vistula River is characterized by the prolonged reproductive period (April-July) with several spawning events (at least two, based on the oocyte diameter distribution). Both males and females sexually mature within the first year of life and are ready to spawn next spring. Considering the species' body size, its fecundity is relatively large and, additionally, the survival of offspring is supported by parental care. Multiple spawning during the prolonged reproductive season facilitates reproductive success and establishment in newly colonised sites. It allows not only to stagger the reproductive effort over a few months but also provides a second chance for breeding in the case of the first spawning failure. Such reproductive strategy of the western tubenose goby is very effective considering our observations, i.e., its rapid dispersal in the inland waters of Poland, as well as its growing abundance in the consecutive years, since the first record in the Vistula River (Grabowska et al. 2008). The western tubenose goby displays reproductive strategy typical for fish invaders that successfully naturalized in central European inland waters, including other Ponto-Caspian gobies, but also species from various families, such as e.g., topmouth gudgeon, Pseudorasbora parva (Temminck et Schlegel, 1846); Amur sleeper, Perccottus glenii Dybowski, 1877; pumpkinseed, Lepomis gibbosus (Linnaeus, 1758); and brown bullhead, Ameiurus nebulosus (Lesueur, 1819). All these species exhibit some features of life-history that differentiate them from the majority of native fish species in central European bioregion sensu Reyjol et al. (2007) (reviewed in Grabowska and Przybylski 2015). Similar divergence in life-history strategy between native and non-native fish species was observed in other regions of Europe and North America (reviewed in García-Berthou 2007).

\section{ACKNOWLEDGEMENTS}

We would like to express our thanks to the Polish Angling Association for a permit to collect fish samples from the Włocławek Reservoir. We are also grateful to Szymon Tybulczuk and Bartosz Janic for their assistance in the field.

\section{REFERENCES}

Ahnelt H., Bănărescu P.M., Spolwind R., Harka Á., Waidbacher H. 1998. Occurrence and distribution of three gobiid species (Pisces, Gobiidae) in the middle and upper Danube region-Examples of different dispersal patterns? Biologia 53 (5): 665-678.

Bagenal T.B., Tesch F.W. 1978. Age and growth. Pp. 101136. In: Bagenal T.B. (ed.) Methods for assessment of fish production in fresh waters. 3rd ed. Blackwell Scientific Publications, Philadelphia PA, USA.

Bij de Vaate A., Jazdzewski K., Ketelaars H.A., Gollasch S., Van der Velde G. 2002. Geographical patterns in range extension of Ponto-Caspian macroinvertebrate species in Europe. Canadian Journal of Fisheries and Aquatic Sciences 59 (7): 1159-1174. DOI: 10.1139/ f02-098

Blanck A., Tedesco P.A., Lamouroux N. 2007. Relationships between life-history strategies of European freshwater fish species and their habitat preferences. Freshwater Biology 52 (5): 843-859. DOI: $10.1111 /$ j.1365-2427.2007.01736.x

Borcherding J., Staas S., Krüger S., Ondračková M., Šlapanský L., Jurajda P. 2011. Non-native gobiid species in the lower River Rhine (Germany): Recent range extensions and densities. Journal of Applied Ichthyology 27 (1): 153-155. DOI: 10.1111/j.14390426.2010.01662.x

Brandner J., Pander J., Mueller M., Cerwenka A.F., Geist J. 2013. Effects of sampling techniques on population assessment of invasive round goby Noeogobius melanostomus. Journal of Fish Biology 82 (6): 2063-2079. DOI: 10.1111/jfb.12137 
Britton J.R., Davies G.D., Brazier M. 2008. Contrasting life history traits of invasive topmouth gudgeon (Pseudorasbora parva) in adjacent ponds in England. Journal of Applied Ichthyology 24 (6): 694-698. DOI: 10.1111/j.1439-0426.2008.01163.x

Cammaerts R., Spikmans F., van Kessel N., Verreycken H., Chérot F., Demol T., Richez S. 2012. Colonization of the Border Meuse area (The Netherlands and Belgium) by the non-native western tubenose goby Proterorhinus semilunaris (Heckel, 1837) (Teleostei, Gobiidae). Aquatic Invasions 7 (2): 251-258. DOI: 10.3391/ai.2012.7.2.011

Copp G.H., Bianco P.G., Bogutskaya N., Erős T., Falka I., Ferreira M.T., Fox M.G., Freyhof J., Gozlan R.E., Grabowska J., Kováč V., Moreno-Amich R., Naseka A.M., Peňáz M., Povž M., Przybylski M., Robillard M., Russell I.C., Stakėnas S., Šumer S., Vila-Gispert A., Wiesner C. 2005. To be, or not to be, a non-native freshwater fish? Journal of Applied Ichthyology 21 (4): 242-262. DOI: 10.1111/j.14390426.2005.00690.x

Erös T. 2005. Life-history diversification in the Middle Danubian fish fauna-A conservation perspective. Archiv für Hydrobiologie 158 (1-2): 289-304. (Suppl. 16; Large Rivers). DOI: 10.1127/1r/16/2005/289

Fox M.G., Vila-Gispert A., Copp G.H. 2007. Lifehistory traits of introduced Iberian pumpkinseed Lepomis gibbosus relative to native populations. Can differences explain colonization success? Journal of Fish Biology 71 (Suppl. D): 56-69. DOI: 10.1111/j.1095-8649.2007.01683.x

García-Berthou E. 2007. The characteristics of invasive fishes: what has been learned so far? Journal of Fish Biology 71 (Suppl. D): 33-35. DOI: 10.1111/j.10958649.2007.01668.x

GeorgievŽ. 1966. Vidovs"staviharakteristika na popčetata (Gobiidae, Pisces) v B"lgariâ. [Species composition and characteristics of the gobies (Gobiidae, Pisces) in Bulgaria.] Izvestiâ na Naučnoizsledovatelskiâ institut za ribno stopanstvo i okeangrafiâ, Varna 7: 159-228. [In Bulgarian.]

Grabowska J., Pietraszewski D., Ondračková M. 2008. Tubenose goby Proterorhinus marmoratus (Pallas, 1814) has joined three other Ponto-Caspian gobies in the Vistula River (Poland). Aquatic Invasions 3 (2): 261-265. DOI: 10.3391/ai.2008.3.2.20

Grabowska J., Przybylski M. 2015. Life-history traits of non-native freshwater fish invaders differentiate them from natives in the Central European bioregion. Reviews in Fish Biology and Fisheries 25 (1): 165178. DOI: 10.1007/s11160-014-9375-5

Grabowska J., Zięba G., Przybylski M., Smith C. 2019. The role of intraspecific competition in the dispersal of an invasive fish. Freshwater Biology 64 (5): 933-941. DOI: $10.1111 /$ fwb. 13275

Harka Á., Bíró P. 2007. New patterns in Danubian distribution of Ponto-Caspian gobies-A result of global climatic change and/or canalization. Electronic Journal of Ichthyology 1 (1): 1-14.
Harka Á., Farkas J. 2006. Wachstum und Laichzeit der Marmorierten Grundel (Proterorhinus marmoratus [Pallas, 1811]) im Theiss-See (Ostungarn). Österreichs Fischerei 59 (8): 194-201.

Hunter J.R., Goldberg S.R. 1980. Spawning incidence and batch fecundity in northern anchovy, Engraulis mordax. Fishery Bulletin 77 (3): 641-652.

Hunter J.R., Lo N.C., Leong R.J. 1985. Batch fecundity in multiple spawning fishes. NOAA Technical Report NMFS 36: 67-77.

Kocovsky P.M., Tallman J.A., Jude D.J., Murphy D.M., Brown J.E., Stepien C.A. 2011. Expansion of tubenose gobies Proterorhinus semilunaris into western Lake Erie and potential effects on native species. Biological Invasions 13 (12): 2775-2784. DOI: $10.1007 / \mathrm{s} 10530-011-9962-5$

Kováč V., Copp G.H., Sousa R.P. 2009. Life-history traits of invasive bighead goby Neogobius kessleri (Günther, 1861) from the middle Danube River, with a reflection on which goby species may win the competition. Journal of Applied Ichthyology 25 (1): 33-37. DOI: 10.1111/j.1439-0426.2009.01189.x

Kovtun I.F. 1979. Significance of the sex ratio in the spawning population of the round goby, Neogobius melanostomus, in the relation to year-class strength in the Sea of Azov. Journal of Ichthyology 19 (1): 161163.

Le Cren E.D. 1951. The length-weight relationship and seasonal cycle in gonad weight and conditions in the perch (Perca fluviatilis). Journal of Animal Ecology 20 (2): 201-219. DOI: 10.2307/1540

Manné S., Poulet N., Dembski S. 2013. Colonisation of the Rhine basin by non-native gobiids: An update of the situation in France. Knowledge and Management of Aquatic Ecosystems 2013 (411): e02. DOI: 10.1051/ $\mathrm{kmae} / 2013069$

Meunier B., Yavno S., Ahmed S., Corkum L.D. 2009. First documentation of spawning and nest guarding in the laboratory by the invasive fish, the round goby (Neogobius melanostomus). Journal of Great Lakes Research 35 (4): 608-612. DOI: 10.1016/j. jglr.2009.08.012

Miller P.J. 1984. The tokology of gobioid fishes. Pp. 119-153. In: Potts G.W., Wootton R.J. (eds.) Fish reproduction: Strategies and tactics. Academic Press, London, UK.

Miranda L.E., Muncy R.J. 1987. Recruitment of young-of-year largemouth bass in relation to size structure of parental stock. North American Journal of Fisheries Management 7 (1): 131-137. DOI: 10.1577/1548-8659(1987)7<131:ROYLBI >2.0.CO;2

Moskal'kova K.I. 1996. Ecological and morphophysiological prerequisites to range extension in the round goby Neogobius melanostomus under condition of anthropogenic pollution. Journal of Ichthyology 36 (8): 584-590.

Murua H., Kraus G., Saborido-Rey F., Witthames P., Thorsen A., Junquera S. 2003. Procedures to estimate fecundity of marine fish species in relation 
to their reproductive strategy. Journal of Northwest Atlantic Fishery Science 33: 33-54. DOI: 10.2960/j. v33.a3

Naseka A.M., Boldyrev V.S., Bogutskaya N.G., Delitsyn V.V. 2005. New data on the historical and expanded range of Proterorhinus marmoratus (Pallas, 1814) (Teleostei: Gobiidae) in eastern Europe. Journal of Applied Ichthyology 21 (4): 300-305. DOI: 10.1111/j.1439-0426.2005.00685.x

Pinchuk V.I., Vasileva E.D., Vasilev V.P., Miller P.J. 2003. Proterorhinus marmoratus (Pallas 1814). Pp. 72-93. In: Miller P.J. (ed.) The freshwater fishes of Europe, Vol. 8, Part II, Gobiidae 2. Aula-Verlag, Wiebelsheim, Germany.

Reyjol Y., Hugueny B., Pont D., Bianco P.G., Beier U., Caiola N., Casal F., Cowx I., Economou A., Ferreira T., Haidvogl G., Noble R., De Sostoa A., Vigneron T., Virbickas T. 2007. Patterns in species richness and endemism of European freshwater fish. Global Ecology and Biogeography 16 (1): 65-75. DOI: 10.1111/j.1466-8238.2006.00264.x

Reynolds J.D., Webb T.J., Hawkins L.A. 2005. Life history and ecological correlates of extinction risk in European freshwater fishes. Canadian Journal of Fisheries and Aquatic Sciences 62 (4): 854-862. DOI: 10.1139/f05-066

Ribeiro F., Elvira B., Collares-Pereira M.J., Moyle P.B. 2008. Life-history traits of non-native fishes in Iberian watersheds across several invasion stages: A first approach. Biological Invasions 10 (1): 89-102. DOI: 10.1007/s10530-007-9112-2

Roche K.F., Janač M., Jurajda P. 2013. A review of gobiid expansion along the Danube-Rhine corridorGeographical change as a driver for invasion. Knowledge and Management of Aquatic Ecosystems 2013 (411): e01. DOI: 10.1051/kmae/2013066

Semenchenko V., Grabowska J., Grabowski M., Rizevsky V., Pluta M. 2011. Non-native fish in Belarusian and Polish areas of the European central invasion corridor. Oceanological and Hydrobiological Studies 40 (1): 5767. DOI: 10.2478/s13545-011-0007-6

Sorokin P.A., Medvedev D.A., Vasil'ev V.P., Vasil'eva E.D. 2011. Further studies of mitochondrial genome variability in Ponto-Caspian Proterorhinus species (Actinopterygii: Perciformes: Gobiidae) and their taxonomic implications. Acta Ichthyologica et Piscatoria 41 (2): 95-104. DOI: 10.3750/AIP2011.41.2.04
Stepien C.A., Tumeo M.A. 2006. Invasion genetics of Ponto-Caspian gobies in the Great Lakes: A 'cryptic' species, absence of founder effects, and comparative risk analysis. Biological Invasions 8 (1): 61-78. DOI: 10.1007/s10530-005-0237-x

Tomczak M.T., Sapota M.R. 2006. The fecundity and gonad development cycle of the round goby (Neogobius melanostomus, Pallas 1811) from the Gulf of Gdańsk. Oceanological and Hydrobiological Studies 35 (4): 353-367.

Top N., Karakuş U., Tepeköy E.G., Britton J.R., Tarkan A.S. 2018. Plasticity in life history traits of the native Proterorhinus semilunaris suggests high adaptive capacity in its invasive range. Knowledge and Management of Aquatic Ecosystems 2018 (419): 48. DOI: $10.1051 / \mathrm{kmae} / 2018032$

Valová Z., Konečná M., Janáč M., Jurajda P. 2015. Population and reproductive characteristics of a non-native western tubenose goby (Proterorhinus semilunaris) population unaffected by gobiid competitors. Aquatic Invasions 10 (1): 57-68. DOI: 10.3391/ai.2015.10.1.06

Vila-Gispert A., Alcaraz C., García-Berthou E. 2005. Life-history traits of invasive fish in small Mediterranean streams. Biological Invasions 7 (1): 107-116. DOI: 10.1007/s10530-004-9640-y

Villeneuve F., Copp G.H., Fox M.G., Stakėnas S. 2005. Interpopulation variation in growth and life-history traits of the introduced sunfish, pumpkinseed Lepomis gibbosus, in southern England. Journal of Applied Ichthyology 21 (4): 275-281. DOI: 10.1111/j.14390426.2005.00679.x

Wootton R.J. 1998. Ecology of teleost fishes. 2 edn. Kluwer Academic Publishers, Fish and Fisheries Series 24, Dordrecht, Boston, London, UK.

Záhorská E., Kováč V. 2009. Reproductive parameters of invasive topmouth gudgeon Pseudorasbora parva (Temminck and Schlegel, 1846) from Slovakia. Journal of Applied Ichthyology 25 (4): 466-469. DOI: 10.1111/j.1439-0426.2009.01190.x

Zar J.H. 2010. Biostatistical analysis. 5th edn. Prentice Hall, Upper Saddle River, NJ, USA.

Received: 29 January 2019

Accepted: 06 June 2019

Published electronically: 15 December 2019 